
Artvin Çoruh Üniversitesi
Orman Fakültesi Dergisi
ISSN:2146-1880, e-ISSN: 2146-698X
Yıl: 2015, Cilt: 16, Sayı:1, Sayfa: 37-39

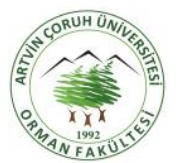
Artvin Coruh University
Journal of Forestry Faculty
ISSN:2146-1880, e-ISSN: 2146-698X
Year: 2015, Vol: 16, Issue: 1, Pages: 37-39
http://edergi.artvin.edu.tr

Araştırma makalesi

\title{
Cinara curvipes (Patch, 1912) (Hemiptera; Aphididae) as new aphid species for Turkish aphidofauna
}

Türkiye afit faunası için yeni bir afit türü: Cinara curvipes (Patch, 1912) (Hemiptera; Aphididae)

\author{
Gazi GÖRÜR, Azize TOPER KAYGIN², Özhan ŞENOL ${ }^{1}$, Hayal AKYILDIRIM BEĞEN ${ }^{3}$ \\ ${ }^{1}$ Nigde University, Science and Art Faculty, Department of Biology \\ ${ }^{2}$ Bartin University, Forestry Faculty, Department of Forest Engineering, Forest Entomology and Protection \\ ${ }^{3}$ Artvin Coruh University, Forestry Faculty, Botany Department
}

\begin{abstract}
Cinara curvipes (Patch, 1912) feeding on Abies sp. and Cedrus sp. were sampled from Afyonkarahisar, Kütahya and Bartın provinces between 2012 and 2014 were determined as invasive and new aphid species for Turkey aphidofauna. The most important implication of the finding is that recording $C$. curvipes from their almost all potential host plant in Turkey.

Keywords: Aphid, Cinara curvipes, invasive, new record, Turkey

Özet

Cinara curvipes (Patch, 1912) türü 2012-2014 yılları arasında Abies sp. ve Cedrus sp. konak bitkileri üzerinden Afyonkarahisar, Kütahya ve Bartın illerinden örneklenmiş ve bu türün Türkiye afit faunası için yeni kayıt ve yayılımcı bir tür olduğu ortaya konulmuştur. Çalışmanın en önemli yanı ise $C$. curvipes türünün literatürde belirtilen muhtemel konak türlerinin hepsinden Türkiye'den kayıt verilmiş olmasıdır.
\end{abstract}

Anahtar kelimeler: Afit, Cinara curvipes, yayılımcı, yeni kayıt, Türkiye.

\section{INTRODUCTION}

Cinara species feed on Coniferae of the families Cupressaceae and Pinaceae. Cinara aphids do not show host alteration and they generally find with ant attended as they produced huge amount of honeydew. They generally feed on the roots, branches, trunk, twigs, shoots and foliage of their host plant. Aptera individuals are bright or dull black and during summer period their bodies are covered by wax powder. They easily recognized with their long legs. Cinara includes about 205 described species, many of these species are native to North America, but also 55 species recorded from Europe and Asia (Favret \& Voegtlin 2004; Gorur et al. 2012; Blackman \& Eastop 2014; URL1). 28 Cinara species has been recorded from Turkey up to now and it was shown that $C$. indica and $C$.juniperensis are invasive for Turkey Aphidofauna (Toper Kaygin \& Canakcioglu, 2003; Senol et al., 2014a; Senol et al., 2014b). Cinara curvipes is originally Nearctic, but now it is widely distributed in Europe, especially in Britain, Germany, Slovenia, Serbia, Switzerland, Slovakia, Czech Republic (Jurc et al. 2009; Blackman \& Eastop 2014; URL1, URL2). Despite C. curvipes was recorded in 1999 in Britain, then spread over most part of the Europe in 15 years and arrived to Turkey in 2012 indicating that how it is important invasive and dangerous species.

\section{MATERIALS AND METHODS}

The field study conducted in Inner Western Anatolian Part of Turkey and Western Black Sea Region from 2012 to 2014. Collected samples were diagnosed according to Blackman \& Eastop (2014) and their current distributions were determined from previous studies (Jurc et al 2009; Blackman \& Eastop 2014; URL1).

\section{RESULTS AND DISCUSSION}

Two samples were collected on Cedrus sp. from 
Kutahya/Aslanapa (24.vii.2012) and Afyonkarahisar (30.vii.2012), 2 samples collected on Abies sp. from Afyonkarahisar/Büyükkalecik/Yuzbaşi Agah Efendi Sehitligi (13.ix.2013) and AfyonkarahisarKocatepe/Buyukkalecik (29.x.2013) and also 2 samples were collected on Abies nordmanniana subsp. bornmulleriana Mattf. in Bartin-Hasankadi (28.iv.2013) and Abies sp. in Bartin-GecenVillage (07.v.2014). It was shown that dense colonies of blackish-grayish individuals of $C$. curvipes fed on branches and stem bark of two potential host plants, Abies sp. and Cedrus sp. (Figure 1). Their body was covered with wax powder. It was also shown that all individuals in the colony reacted to irritation with rocking motion.

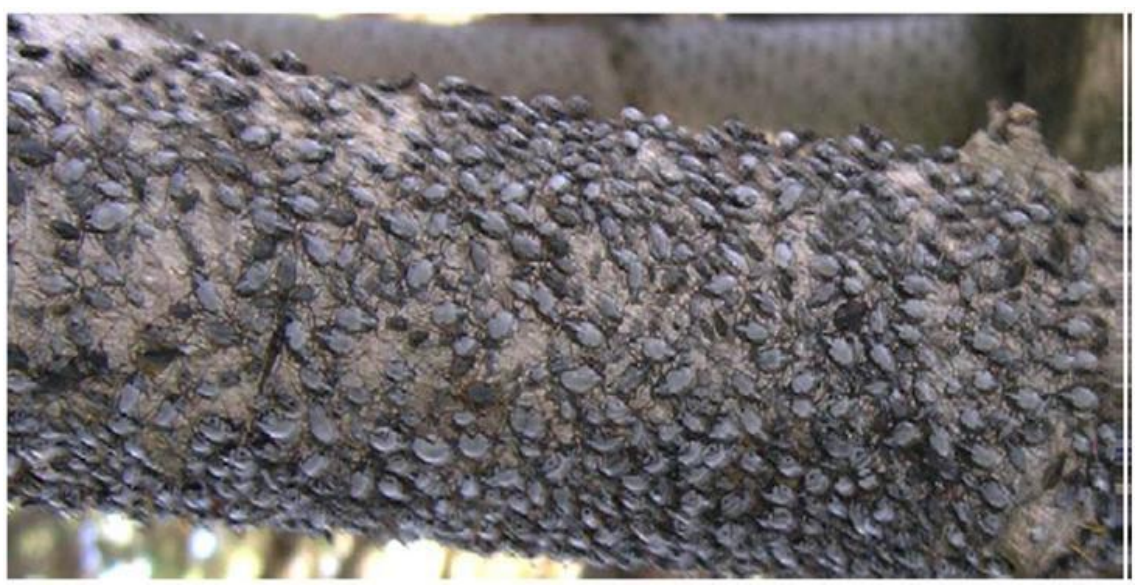

Figure 1. Dense colonies of $C$. curvipes feed on branch of Abies sp. (by GORUR).

It was shown that $C$. curvipes colonies are heavily visited by ants as they produced huge amount of honeydew. For example, heavily colonized population on 60 years old Abies nordmanniana subsp. bornmulleriana and 15 years old Abies sp. produced tremendous honeydew and visited by and as expected, but aesthetically damaged the colonized parts of both plants and caused sooty moulds (Figure 2). They almost caused the death of young Abies sp. These findings are parallel with the Poljakovic-Pajnik \& Petrovic-Obradovic (2002) finding and discussions. There were also many multicolored Asian lady beetle, Harmonia axyridis (Pallas), consumed considerable number of the $C$. curvipes individuals on some young Abies trees (Figure $3 a$ and $3 b$ ).

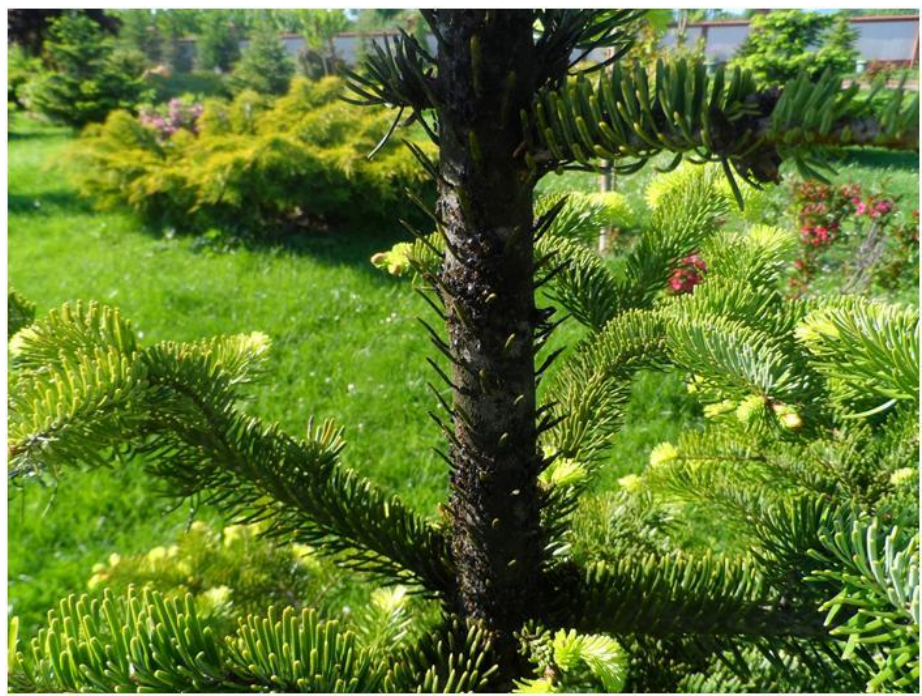

Figure 2. C. curvipes colonies, honeydew production and caused sooty moulds (by TOPER KAYGIN). 

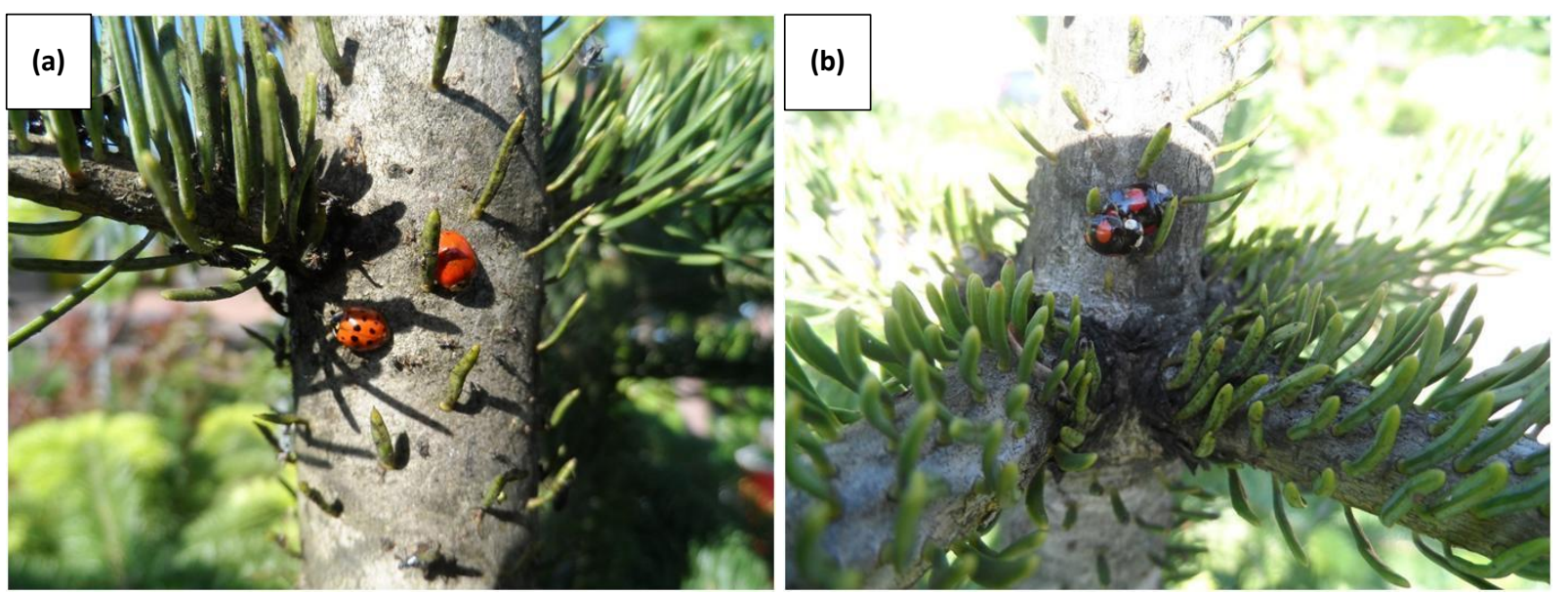

Figure 3. (a and b) Harmonia axyridis (Pallas) Multicolored Asian Lady Beetle (by TOPER KAYGIN).

\section{ACKNOWLEDGEMENT}

Authors thank to the Turkish Scientific Council (TUBITAK-Project number 111T866) for partially supporting this study.

\section{REFERENCES}

Blackman R, and Eastop V (2014) Aphids on The World's Plant. An Online Identification and Information Guide. Available from: http://www.aphidsonworldsplants.info.

Favret C and Voegtlin DJ (2004) Speciation by host-switching in pinyon Cinara (Insecta: Hemiptera: Aphididae). Molecular Phylogenetics and Evolution, 32: 139-151.

Gorur G, Akyildirim H, Olcabey G and Akyurek B (2012) The Aphid Fauna of Turkey: An Updated Checklist. Archives of Biological Science Belgrade, 64 (2): 675-692.

Jurc M, Poljaković-Pajnik $L$ and Jurc D (2009) The First Record of Cinara curvipes (Patch, 1912) (Homoptera, Aphididae) in Slovenia and Its Possible Economic Impact. Zbornik Gozdarstva in Lesarstva, 88: 21 - 29.
Martin JH (2000) Two New British Aphid Introductions in 1999, in the Context of Other Additions over the Preceding Thirty Years (Sternorrhyncha: Aphidoidea). Entomologist's Gazette 51 (2), 97-105.

Poljaković-Pajnik L and Petrović-Obradović O (2002) Bow-Legged Fir Aphid Cinara curvipes (Patch) (Aphididae, Homoptera) New Pest of Abies concolor in Serbia. Acta Entomologica Serbica, 7 (1/2): 147-150.

Senol O, Akyildirim H, Gorur G and Demirtas E (2014a) New Entry for the Turkey Aphidofauna [Hemiptera: Aphidoidea]. Acta Zoologica Bulgarica 66 (1): 133-136.

Senol O, Akyildirim Begen H, Gorur G. and Demirtas E (2014b) New Additions and Invasive Aphid to Turkey Aphidofauna [Hemiptera: Aphidoidea]. Turkish Journal of Zoology (In Press).

Toper Kaygin A, and Canakcioglu H (2003) Contributions to the knowledge of conifer aphid fauna in Turkey and their zoogeographical distribution. Anzeiger Schodlingskunde 76:50-56.

URL1 (http://www.influentialpoints.com). 21.11.2014.

URL 2 (http://www.faunaeur.org/distribution_table.php). 24.11.2014. 